\title{
Tarih Metodolojisinde Laboratuar Yöntemi ve Safranbolu Örneği
}

\author{
History Methodology Laboratory Method and Safranbolu Sample
}

\section{Yüksel Kaştan}

Türkçe ve Sosyal Bilgiler Eğitimi Bölümü, Akdeniz Üniversitesi, İstanbul, Türkiye

\begin{abstract}
Özet
Bernheim, tarih metodolojisini tarihi yazım tarzı olarak algılamaktadır. O, bunu üç kısma ayırmıştır; hikaye eden tarz, öğreten tarz, araştıran tarz. Araştıran tarih her hangi bir coğrafyada laboratuar yöntemi ile tarihteki bir kesit, tarihteki bir süreç incelemeye alınarak elde edilen bulguların sorgulanarak bir sonuca varılmasıdır. Bu yöntemle tarih içinde belirli bir zaman dilimi ve geçen süreç incelenir. Ayrıca bugün anlatılırken geçmiş olaylardan sondajlama ve örnek olay yöntemi kullanılır. Böylece laboratuar yöntemi ile geçmişi incelerken tamamen fen bilimleri gibi bilimsel verilerden yararlanılarak nesnelliğe yaklaşılır. Bu yöntem ile bir coğrafyanın nüfusu, ekonomisi, siyasi durumu, inanışları, kısaca sosyal, ekonomik ve kültürel yapısı tamamen belirlenmiş olur. Bu nedenle yöntem tarih bilimi için son derece önem taşır.

Safranbolu Osmanlı Devleti'nin son dönemi ile ilgili çok önemli taşınmaz ve taşını varlıklara sahip bir kenttir. Kent bu özelliği ile dünya miras kentleri listesine alınmıştır. $\mathrm{Bu}$ çalışmada araştıran tarih metodolojisi içerisinde yer alan laboratuar yöntemi kullanılarak Safranbolu kenti incelenmiştir.
\end{abstract}

Anahtar Kelimeler: Tarih, metodoloji, laboratuar, Safranbolu.

\section{Abstract}

Bernheim perceives history methodology as a historical writing style. He divided it into three parts; Storytelling style, teaching style, research style. The investigating date is a cross section in the history with a laboratory method in any geography, and a result is obtained by inquiring the findings obtained by examining a historical process. With this method, a certain period of time and the process in history are examined. In addition, today's events are based on sounding and case studies from past events. Thus, while studying the past with the laboratory method, objectivity is approached by using scientific data such as science completely. With this method, the population, economy, political situation, beliefs, social, economic and cultural structure of a geography are determined completely. For this reason, the method is extremely important for the history of science.

Safranbolu is a city with very important immovable and movable assets related to the last period of the Ottoman State. With this feature, the city has been taken to the list of world heritage cities. In this study, Safranbolu city was investigated by laboratory method which is included in research methodology.

Keywords: History, methodology, laboratory, Safranbolu.

CONTACT : Yüksel Kaştan, kastanyuksel@hotmail.com

Geliş Tarihi \& First Received : 06.06.2017

Kabul Tarihi \& Accepted $\quad$ : 24.07.2017 


\section{Giriş}

Kâinatın oluşumu bütün bilim insanlarının ilgi alanına girmiştir. Dünyanın oluşumu, ilk insanlar, insanlık tarihi, kültür ve medeniyetlerin tarihi merak konusu olmuştur. Tarih yazının icadı ile başlamış olmasına rağmen tarihten önceki devirler de tarihin konusu içine girmiştir. İlk tarihi kayıtları Heradot'un tutmasından dolayı kendisi tarihin babası olarak isimlendirilmektedir. Daha sonraları eleştirel tarih anlayışı başlamış, fakat tarih bilimi ile ilgili esas gelişmeler 18.yüzyılda Avrupa'da başlamıştır. Tarih 19. yüzyılda bilim olarak kabul görmüştür. Bu kapsamda tarih tarihin bilim mi, yoksa değil mi olduğu konusunda Bernheim "Tarih ilmi; insanların zaman ve mekan itibariyle geçirdikleri tekamülleri birlikte yaşayan canlı mahluk sıfatıyla yapa geldikleri psikofizik hareketleri, bunların illi münasebetlerine izafe edilen müşterek kıymetleri araştırır ve tasvir eder." demekte ve ayrıca "Biz tarihi ilim olarak görürüz..., vakıaların muayyen bir sahada illi münasebetlerini tanımak istediğinden tarih bir ilimdir"" diye belirtmektedir. Tarihin mevzuu konusunda da kısaca "insanın yaptıklarıdır" diyerek insanın tüm geçmişinin tarihin konusu olduğunu ima etmektedir. Tarihi olaylarda zaman ve mekân konumunun yanında bu olayı gebe edici diğer faktörlerin de olduğunu hesaba katmak bir bütünlük içinde tarihi olayların en gerçekçi şekilde açıklanabileceği görüşünü taşımaktadır. Tarih bilimi faydalı mıdır veya ne derece yararlıdır sorusuna ise O'nun şu cümleleri 1şık tutmaktadır: "Tarih ilmi bize; geçmiş hadiselerin ve vaziyetlerin ne suretle ve nasıl olduklarını ögreterek hali dolayıslyla insanları ve kendimizi tanitır ve geleceğin de nasıl olabileceğini gösterir. Aynı zamanda, bir maksada dayanan fikralarla ahlak hocalı̆̆ yapmaya kalkuşmaksızın önce anlatılan evsafi sayesinde yüksek manevi bir vazifeyi ifa eder: ferdin ve sosyal grupların her faaliyetini külli ve genel tekamül ile çok sılk ilişkili görmeyi ögretir ve bu yol ile külliyet ve genelliğin fertler ve bütün insansal cemiyetler için ehemmiyetini canlı bir surette anlatır. İste bunların hepsi, cemiyet duygusunun ahlaksal şuurunu bir düzeye ikaza ve hırs suretinde kendini gösteren yıkıcı benlikten bir düzeye ihtiraza yararlar...Yani tarih ögretimi; yurt sevgisinin beslenmesine yarayan en mühim amildir...Tarih ilminin ruhunda bizatihi mevcut olan ferdin içinde yaşayıp savaşstı̆̆ cemiyetle canlı irtibatı olmadıkça kendisinin bir hiç olduğunu telkin etmek gibi yüksek ahlaki ideal yanında artık ham, tarafgir maksatlar yer tutamazlar" "2. Burada Bernheim açıkça belirttiği gibi bir milletin millet olabilmesi için mutlaka tarihine sahip çıkması ve bir tarih içinde yer alması gerekmektedir. Tarihini iyi bilmeyen insan, lider ve halk zamanla yozlaşma içinde başka nüfuzların etkisine, başka çekim alanlarına girerler.

Osmanlı Devleti'nin son dönemlerinde de ülkede tarih ve tarih bilimine önem verilmiştir. Üniversitede tarih kürsüsü açılmış, tarih ders olarak okullarda okutulmuştur. Türkiye Cumhuriyeti'nin kuruluşundan kısa bir süre sonra Türk Tarihini Tetkik Cemiyeti 1931 yılında kurulmuş, daha sonra tarih kongreleri düzenlenmiştir. Cumhuriyet döneminin önemli düşünce adamlarından İsmet Zeki Eyuboğlu, "Tarihin İlkeleri” adlı eserinde yine "Tarihin İlkeleri” adlı bölüm içinde tarihin özellikleri hakkında bilgi vermektedir. Buna göre tarihte öncelikle önyargı ve katılaşma olmaz. Tarihin ilkeleri olarak ele aldığı konulardan ilki kendini kanıtlamadır, bu ise insanın evrende varlığını ve kendisini kanıtlaması anlamına gelmektedir. Tarihin ikinci ilkesi yaratma olayıdır. İnsanoğlunun devingen yaratılışı itibariyle sürekli yenilik ve araştırma gayreti içinde olduğundan yeni buluşlar ve yaratmaların ortaya çıkmış olmasını bu ilke açıklamaktadır. Diğer bir ilke olan kendini kanıtlamada temel etken dil olmakta ve dil sayesinde insanlar araştırma, inceleme ve bulgularını kanıtlayabilmektedirler. Düşünmek ise diğer bir ilkedir ve düşünme her toplum yapısında farklı meydana gelmektedir, bu da o toplumun düşünce ve felsefe yapısını gösterir. Tarihte

\footnotetext{
${ }^{1}$ E. Bernheim, a.g.e, s.51; Arnold J. A. Toynbee, (1978), Tarih Bilinci, Bateş Yayınları, İstanbul, s. 172; Grace Cairns, (1962), Philosophies of History, New York, s.31-32.

${ }^{2}$ E. Berheim, a.g.e, s.62; A. Pitirim Sarokin, (1972), Bir Bunalım Çă̆ında Toplum Felsefeleri, Çev. Mete Tuncay, Ankara, s. 59; Arnold J. A. Toynbee, (1953), Civilization on Trial, London, s. 30.
} 
olaylar süreklilik içindedir ve her hadise yeni bir hadisenin oluşmasına vesile olur ve süreklilik kazanamayanlar yok olmaya mahkûm olarak tarihin sayfalarından silinir giderler, süreklilik te o halde tarihin ilkeleri arasındadır. Süreklilik ilkesinden sonra yargılama ve eleştiri ilkeleri gelmektedir ki esasen tarihi bilim yapan bulguların ve çalışmaların yargılanması ve eleştirilmesidir. ${ }^{3}$

Tarih sadece geçmişi araştırıp bilimsel olarak ortaya koymak mıdır, yoksa tarihten dersler çıkarıp yapılan hataların tekrar yapılmaması için uğraşmak mıdır? Son zamanlarda tarihçiler arasında tarihin faydası nedir ve ne olmalıdır konusu giderek tartışılmaya başlamıştır. "Tarihin Peşinde" adlı eserinde Tosh, tarih bilimi üzerinde fazla durmayarak daha çok "Tarihin Faydaları" bölümünde tarihin oluşumu, faydaları ve farklı tarih yazıcılığı anlayışına önem vermiştir. $\mathrm{O}$ daha ziyade tarih ilminin bir milletin hayatında, dünya düzleminde oynadığı etkin rolü ayrıca devlet ile toplumsal olayların nasıl yazıldığında hem bugünkü hem de gelecek nesiller üzerinde olumlu güdüleme yapabileceği hususunda fikirlerini beyan etmektedir. Tosh daha çok tarih ilminin bir milletin hayatında ya da dünya düzleminde ne gibi etkin rol oynadığ ve devlet ile toplumsal olayların asıl yazıldığında bugünkü nesil ve ileriki nesiller üzerinde olumlu motive yapabileceği üzerinde fikirlerini beyan etmektedir. Ranke de bu konuda "Tarih, geçmişin muhakemesini yapma, gelecek çağların yararına bugün için dersler çıkarma görevini üstlenmiştir. Bu çalışma, böyle yüce işlevlere yönelik değildir. Amaç, geçmişte gerçekten neler olup bittiğini göstermektir sadece." ${ }^{\prime 4}$ diyerek görüşlerini belirtmektedir. Collıngwood' ise yine aynı konuda "Tarih Tasarımı" adlı eserinde kısaca "Bilim şeyleri aramadır: Bu anlamda da, tarih bir bilimdir." diyerek tarih hakkındaki görüşlerini özetlemiştir.

\section{Tarih Bilimi Ve Laboratuar Yöntemi Süreci}

Öncelikle "Tarih” kelimesinin etimolojisine bakıldığında birkaç farklı tanımı görülebilir. Bunlardan bazıları şöyledir: Uçar'a göre ibranice "venche" kelimesinden gelmekte ve anlamı "hilali görmek" demektir... Tarih kelimesi hadiselerin tarihi tespit etmek (...) demektir, Yunanca "istoria" kelimesi "tek tek araştırma ve inceleme" anlamını vermektedir. Arapca ise "usture" kelimesi efsane anlamını taşımaktadır ${ }^{6}$. İlk zamanlarda tarih sadece olan biteni kaydetmek olarak algılanmış ve uzun zaman bu düşünce devam etmiştir. Sait Başer ise tarih yazıcıllı̆ı hakkında "olup biten hadiselerin hikmetine ulaşma ve hangi ilahi ilimlerin tecellilerini taşıdığını keşfetme ilmidir"7 demektedir. Ünlü tarihçi İbn-i Haldun ise tarih konusunda " Tarih, insanların ve kavimlerin hal ve durumlarının nasıl değişmiş olduğunu, devlet sınırlarının nasıl genişlemiş, kudret ve kuvvetlerinin nasıl artmış bulunduğunu, ölüm ve yıkılma çağı gelinceye kadar yeryüzünü nasıl imar ettiklerini bize bildirir. Bu tarihin zahiri (açık, anlaşılan) manasıdır. Tarihin içinde saklanan ise, incelemek, düşünmek, araştırmaktan ve varlığın (Kainatın) sebep ve illetlerini dikkatle anlamak ve hadiselerin vukuu ve cereyanının sebep ve terkibini inceleyip bilmekten ibarettir. İște bundan dolayı tarih şereflidir ve hikmetin içine dalmıştır." birbirinden ayrılıyor. Bunlardan birincisi, objektif tarihi süreç, ikincisi ise bu sürecin tasviri, tahlili ve hikayesidir. Yani tarih kavramı, bir taraftan, dışarıdan tanıyan bir zihinden bağımsız olarak

\footnotetext{
${ }^{3}$ Onay Sözer, (1983), "Dünya Tarihi ve Özgürlük İfadesi ", Macit Gökberk Armağanı, Ankara, s. 117; Karl Lowith, (1984), Vico, Çev. Doğan Özlem, Tarih Felsefesi Eki, İzmir, s.85.

${ }^{4}$ Leon von Ranke, (1952), Histories of the Latin and German Nations from 1494 to 1514,2.Bask1, Longman, s.74.

${ }^{5}$ R. G. Collıngwood, (1990), Tarih Tasarımı, Çev. Kurtuluş Dinçer, Ara, İstanbul, s.24.

${ }^{6}$ Şahin Uçar, (1994), Tarih Felsefesi Yazıları, Ankara, s.11-12.

${ }^{7}$ Sait Başer, (1995), Kutatgu Bilig'de Kut ve Töreden Sevgi Toplumuna, İstanbul, s.167; Mustafa Aksoy, (1997), Doğu Anadolu, İstanbul, s.19.

${ }^{8}$ Ümit Hassan, (1982), İbn Haldun: Metodu ve Siyaset Teorisi, Sevinç Matbaas1, Ankara, s.136; İbni Haldun, (1991), Mukaddime, C1, Çev: Z. K. Ugan, İstanbul, s.5.
} 
varolan gerçekliği; diğer taraftan, bu gerçekliğe ait araştırma ve düşünceyi ifade etmektedir"’ diyerek görüşlerini bildirmektedir.

Yukarıda yapılan tanımlara bakıldığında tarihte nesnellik ve öznellik konularının geçtiği görülecektir. Hiç bir tarihçi tam anlamıyla nesnel olamaz, mutlaka bir kültür içinde yaşadığı ve diğer bireylerden farklı olduğu için elbette o da tarihi meselelere farklı yaklaşacak, farklı bir çözüm bulacaktır. İşte bu tarz ile ancak nesnel tarihçi olunabilir. Bugünkü modern çağı yakalayan kültür ve toplum, Batı toplumudur. Fakat dünyada sadece Batı toplumu yaşamamaktadır. Daha birçok yaşayan ve ölen toplumlar bulunmaktadır. Ama tarih her zaman ayakta kalabilen toplumlarla ilerleme kaydetmiştir. Bu nedenle Batı toplumunu bu seviyeye getiren tarihin gelişim safhalarının incelenmesi gerekmektedir. Batı toplumunun tarih felsefesi Antik Yunan çağında Heredot'la yapılanmaya başlamıştır. O zamanlar şehir devletçiliği olduğu için daha çok mitoloji ve devlet tarihi yazılmıştır. Bu zamanlarda "araştıran tarih" anlayışı yerine daha çok "olay tarihçiliğgi" hüküm sürmüştür. Tarihin insanların yaptığı şeylerle ilgili olduğunu Heredot kavrar, Thukydides ise ilk defa "tarihsel araştırmanın kanıta dayandığı" görüşünü ileri sürerek bir ilerleme kaydeder. ${ }^{10}$

Antik tarih felsefesi tekildir, evrensel değildir ve sadece kendi ülkelerine göre tarih yazar. $\mathrm{Bu}$ zamanda tarih anlayışı "Tarih insan eylemine ilişkin bir bilimdir: tarihçinin önüne koyduğu, insanların geçmişte yaptıkları şeylerdir, bunlar da bir değişme dünyasına, şeylerin var olup yok olduğu bir dünyaya aittir." Buna göre Yunan düşüncesinde bilgi ve sanı olan iki kavram yer almaktadır: "Sanı, değişmekte olan olgular hakkında edindiğimiz deneysel yarı-bilgidir. Dünyanın gelip geçici gerçeklikleri ile gelip geçici tanışıklığımızdır; onun için, ancak kendi süresi için, şimdi ve burası için geçerlidir; dolaysızdır, gerçeklerle temellendirilmemiştir, tanıtlanamaz. Doğru bilgi ise, tersine, yalnız şimdi ve burası için değil, her yerde ve her zaman geçerlidir; tanıtlayıcı uslamlamaya dayanır ve diyalektik eleştirinin silahlarıyla hatayı görüp yenebilir."11

Yunan toplumuna Hellenlerin de dâhil olması ile tarihte yeni bir anlayış ortaya çıkar. Bu anlayış evrensel tarih anlayışıdır, zira bu zamana kadar tek uluslu olan devlet bundan sonra çok ulusluluğa geçmektedir. Daha sonra Roma Devleti zamanında ise tamamen "devlet tarihçiliği” takip etmiştir. Ayrıca Roma tarihinde tözcülük, yani verilere dayalı çalışma önemli bir yer tutar. ${ }^{12}$

Ortaçağ tarihçiliği ise nesnel tarihçilik ile kilise tarihçiliği arasında yer almıştır. Ortaçağda Batı gelişme kaydedemezken İslam felsefecileri ve tarihçileri bir hayli ilerleme kaydederek batıya 1şık tutar hale gelmiştir. Tarih felsefesi olarak daha çok verilere, olaylara ve devlet tarihçiliği ilk dinlerle ilgili tarihçilik yapılmaktadır. Fakat bu süreç aydınlanma ile birlikte kesintiye uğrar ve artık Tanrı yerine akıl ve doğa kanunları geçmeye başlar, böylece deneye dayalı evrensel tarih anlayışı gelişir. Herder'in "İdeen zur Philosophie der Menschengeschichte" ve Kant'ın "İdeen" ve "İdee an einer allgemeinen Geschichte in weltbürgerlicher Absicht" eserlerinin büyük tesiriyle artık dünyada geçerli olan metafizik yasaları olur. Bu nedenle tarihe fazla önem verilmez ve tarihi olaylar da tabiat

\footnotetext{
${ }^{9}$ Bahaeddin Yediyıldı, "Çağdaş Tarihçilik", Tarih Metedolojisi ve Türk Tarihinin Meseleleri Kollokyumu (Haz. Abdülkadir Yuvalı), Elazığ, 1990, s.25.

${ }^{10}$ Doğan Ergun, (1982), Sosyoloji ve Tarih, İstanbul, s. 66; Doğan Özlem, (1986), Kültür Bilimleri ve Kültür Felsefi, İstanbul, s.8; Eyüboğlu, İ. Z.(1991). Tarihin İlkeleri, İstanbul: Say Yay.

${ }^{11}$ R. G. Collıngwood, a.g.e, s.39; L. Levey Bruhl, ( 1970), Comte Felsefesi ve Sosyolojisi, Çev. Z.F. Fındıkoğlu, İstanbul, s. 160; Heikki Saari, (1998), "Collingwood'un Mutlak Ön-kabuller Öğretisinin Bazı Yönleri", Çev. Kubilay Aysevener, Doğu Batı, 1998/3, Sayı 3, s. 161-174.

${ }^{12}$ Macit Gökberk, (1948), Kant ve Herder'in Tarih Anlayışları, İstanbul, s. 54; Karl Marx, Friedrich Angels, (1975), Felsefe incelemeleri, Çev. Sevim Belli, Ankara, s. 52.
} 
kanunlarıyla açıklanmaya çalışılır. 18.yüzyılda tarih bir gösteri olarak kabul edilerek tarihsel süreçleri iklim bilgisi yasaları ile insan biyolojisi yasalarına indirgenir. ${ }^{13}$

Tarih felsefesine Hegel yeni bir boyut getirir. O, tarihin doğa olayları ile açıklanamayacağı, doğa ile tarihin farklı şeyler olduğunu ileri sürer. Doğa olayları belirli zaman periyotlarında tekrarlanılırken, tarihsel olaylar hiç bir zaman tekrarlanamamaktadır, sadece bazı olaylarda benzerlikler göstermektedir. Hegel yeni bir tanımla "İnsanların ne yaptıklarını bilmek değil, ne düşündüklerini anlamak; tarihçinin işidir." ${ }^{14}$ artık tarih yazımında olayların sorgulanması ve zihinde tekrar canlandırılmasını öne çıkarmaktadır. Daha da devam ederek tarihsel sürecin akılla ilişkili olduğunu savunur, bunun için "tarihte olup biten her şeyin insan istenciyle olup bittiğidir, çünkü tarihsel süreç insan eylemlerinden oluşur; insan istenci ise, insanın eylemde dışsal olarak kendini dile getiren düşüncesidir..." ${ }^{\prime 15}$ savını ortaya koyar.

Hegel'den sonra Marx'ın toplumu yönlendirenin ekonomik çıkar ve şartların olduğunu ileri sürmesi sonucu tarihte yeni bir yaklaşım ortaya çıkar. Artık tarih geçmişi inceleyen ekonomik nedenler penceresinden incelemeye başlar; tabii ki hala materyalist, deneye ve akla dayalı bir anlayışla. Pozitivizmle birlikte " pozitivist tarih anlayışı” gelişmeye başlar. Buna göre öncelikle olgular belirlenecek ve bu olgular daha sonra yasalarla biçimlenmeye çalışılacaktır. Yasalar olgulardan "tümevarım" yöntemi ile genelleme yapılarak çıkarılacaktır. Artık tarihsel dizgecilik, yani ayrıntılar ön plana çıkmış ve bir laboratuar çalışması gibi her şey ardı ardına konarak tarih yazıcılığı yapılmaya çalışılmaya başlanır. Böylece evrensel tarih anlayışından uzaklaşılmasıyla monografi tarihsel yazın ülküsü haline getirilir. ${ }^{16}$

19.yüzyılın sonuna doğru İngiltere'de Bradley'le birlikte tarih anlayışına yeni bir boyut getirilir, bu da eleştirel tarihtir. Buna göre yetkelerin herhangi bir olguyu nasıl olduklarını söylemesine inanılması yanında, bunların doğru olup olmadığına karar verecek olanın yetkeler değil benim zihin süzgecim olmalıdır görüşü doğarken artık yavaş yavaş tarihsel yazında eleştiri de ön plana çıkar. ${ }^{17}$

Windelband, doğa ile tarih arasında fark olması nedeniyle ikisinin de çalışma tarzlarının değişik olacağı düşüncesini ortaya koyar. O'na göre “Tarih ile bilimin her biri kendine özgü bir yöntemi olan iki farklı şey olduğunu; bilimin amacının genel yasaları dile getirmek, tarihinki ise tek tek olguları betimlemektir." Windelband ilk defa "nomotetik bilim" (bilim ve idiografik bilim, tarih) anlamına gelen yeni bir kavram ileri sürer. ${ }^{18}$

İlk defa Ranke ile birlikte tarihte olay anlatıcılığından arşiv çalışmasına göre verilere ve olgulara dayalı tarih yazıcılığı başlar, fakat bu da çok dizgeci olmuş, kendini sorgulama ve tenkit etmez. Bundan dolay arşiv çalışmasından vazgeçilmemiş, fakat çalışmalar da aynen bulunduğu gibi değil tenkit ve yargılama sonucunda bir terkip ile sonuca bağlanmıştır.

\footnotetext{
13 Önay Sözer, (1981), Anlayan Tarih, İstanbul, s. 36; İ.Q. Herder, (1984), Insanlık Tarihi Düşüncesi Üzerine Düşünceler, Çev. Doğan Özlem, Tarih Felsefesi Ek-2, İzmir, s. 192.

${ }^{14}$ R. G. Collıngwood, a.g.e, s.125; Önay Sözer, (1977), Edmund Husserl'in Fenomenolojisi ve Nesnelerin Varliğl, İstanbul, s. 26 ; John R. Hogan, (1989), Collingwood and Theological Hermeneutics, College Theology Society, New York, s. 51.

${ }^{15}$ William Debbins, (1965), Essays in the Philosophy of History by R. G. Collingwood, University of Texas Press, Austin, s. 137; R. G. Collingwood, a.g.e, s.125; Nermi Uygur, (1972), Edmund Husserl'de Başkasının Ben'i Sorunu, İstanbul, s. 102.

${ }^{16}$ Macit Gökberk, a.g.e. s. 156; R. G. Collıngwood, age, s.135; Nathan Rotenstreich, (1976), Philosophy, History and Politics (Studies in Contemporary English Philosophy of History), Martinus Nijhoff- The Hague, s. 25.

${ }^{17}$ John P. Hogan, a.g.e. s. 10; Eric Hobsbawm, (1999), Tarih Üzerine, Çev. Osman Akınhay, Bilim ve Sanat yayınlan, Ankara, s.48.

${ }^{18}$ Albert Hofstadter, (1963), "The Philosophy in History", Philosophy And History, Ed. Sidney Hook, New York University Press, s. 227-249; Erich Rothacker, (1990), Tarihselcilik Sorunu, Çev. Doğan Özlem, Ara Yayıncılık, İstanbul ,s.72.
} 
Artık sırası ile betimleyici tarih felsefesi, yapısalcı tarih felsefesi yerini almakta ve hatta tarihin bilim mi yoksa değil mi tartışmaları yapılmaya başlamıştır. Hatta bu nedenle "tarihisicilik" gibi tarihe benzeyen anlamında bir kavram bile geliştirilmiştir. 20. yüzyılda Fransa'da Annales Okulu'nda Bloch ve Fevbre ile birlikte tarihte yeni bir yaklaşım doğmuştur. Bu da "tümden gelim" değil "tümevarım" metodudur. Buna göre bir çevre belirlenir ve burası belirli zaman diliminde tüm boyutları ile incelenerek buradan bir genelleme yapılır. Mutlaka irdelenerek zaman öncesi olaylarının bu olgulara etkisi olmuştur ve bu olguların sonuçları da yeni olgular meydana getirmiştir. İşte tüm bunların bulunabilmesi için, nasıl bir doğa bilimcinin laboratuara girdiği gibi araştırmacının da herhangi bir coğrafi bölgeyi didik didik tüm yönleri ile incelemesi sonucunda, bulgularını sorgulama ve muhakeme izlenceleri doğrultusunda bir neticeye vardırması gerekmektedir. Bu tür tarih felsefesinin en güzel örneklerinden birini Braudel, II. Felipe Dönemi’nde “Akdeniz Dünyas1 incelemesi" ile vermiştir.

\section{Laboratuar Yönteminde Kaynakların Önemi}

Leon-E.Halkın '1n "Tarih Tenkidinin Unsurları" adlı eserinde "Tarih Tenkidi ve Tarih" adlı bölümde sorgulama ve terkip safhası, tarihte doğruyu yanlıştan ayırt edebilecek yegâne aracın tenkit olduğu ayrıca tarihin şahitliklere dayalı yazıldığı için de öncelikle şahitlikleri araştırmak, onları kontrol etmek ve onları anlamak yani terkip etmek şeklinde vurgulanmıştır. Bunu daha açık bir ifadeyle Halkın "Tarih tenkidinin rolü, doğru, muhtemel, mümkün, inanılmaz, yanlış, yalan, doğrulanması imkânsız olanı ayırt etmekten ibarettir." diye belirtmektedir ${ }^{19}$. Halkın eserinde tarih oluşumunun tersine çevrilemeyeceği, sadece yanlış aktarımların araştırılarak gerçeğe kavuşturulabileceği, tarihte ayakta kalanın önemli olduğu ve bugünün meselelerini aydınlığa kavuşturmanın yegane çaresinin geçmişi analiz etmekten geçtiğini belirtmektedir. Bunun da tarihi algılama felsefesinin sağlam temellere oturmasıyla mümkün olabileceğini ifade etmektedir. Tarihin faydası konusunu ise bir cümle ile özetlemektedir: "İnsan geçmişini ne kadar iyi tanırsa, onun o ölçüde daha az kölesi olur." ${ }^{20}$

Tarih tenkidinin işlemleri ve kaidelerine de Halkın eserinde yer vererek bunu iç tenkitler (metnin içeriğinin doğruluğu, gerçekliğini ilgilendirenler) ve dış tenkit (metnin oluşumu sırasında metin dışındaki olayların gerçekliği ile ilgilidir) olmak üzere iki kısma ayırmıştır. Bu konu Tosh'un eserinde "Tarih Yazıcıllı̆ı" kısmında ele alınmış ve metinlerde kullanılan dilden yola çıkarak tenkitlerle metnin gerçek anlamını ortaya çıkarma anlatılmıştır.

Tarih biliminde kaynak kullanımı oldukça önemlidir. Kaynaklara ulaşma zor olmakla beraber ulaşılan kaynağın güvenilir olması, döneme ait ve dönemi yansıtması gerekmektedir. Tosh eserinde "Kaynak Kullanımı" başlığı altında kaynaklara ulaşma, ulaşılan kaynakların analizine değinmektedir. O da aynen Halkın gibi kaynaklarda iç ve dış tenkitlerden bahsederek devamlı tarih yazarının kuşkucu olması, her bulduğu kaynağı sorgulayarak şüpheyi yok edinceye kadar uğraşması gerektiğini söyler. Aksi halde güvenilir bir veriye ulaşılamayacağı ya da yanıltıcı sonuçlara varılabileceğinden bahseder. ${ }^{21}$

Tarih hakkında Durant'ın “Tarihin büyük bölümü tahmin, geri kalanı ise önyargıdır... Tarihçi her zaman basitleştirir. Tam olarak anlayıp kavrayamadığı olaylar ve insanlar kalabalığından,

\footnotetext{
${ }^{19}$ L .E .Halkın, (1989), Tarih Tenkidinin Unsurları, Çev. Bahaeddin Yediyıldız, Türk Tarih Kurumu Yay., Ankara, s.4.

${ }^{20}$ David West, (1998), Kıta Avrupası Felsefesine Giriş, Çev. A. Cevizci, Paradigma Yay., İstanbul, s. 148; P. Rabinow, W. Sullivan, (1990), "Yorumcu Eğilim: Bir Yaklaşımın Doğuşu”, Toplum Bilimlerinde Yorumcu Yaklaşım, Çev.: Taha Parla, Hürriyet Vakfı Yayınları, İstanbul, s.7.

${ }^{21}$ John Tosh, (1991), The Pursuit of History; Aims, Methods, and... (Tarihin Peşinde, Çev. Özden, Arıkan), Longman, London, s.54-72; J. Habermas, (1998), Sosyal Bilimlerin Mantığı Üzerine, Çev. Mustafa Tüzel, Kabalcı Yay., İstanbul, s.310.
} 
üzerinde rahat çalışabileceği belgeleri ve kişileri seçer ...Tarih yazarlığı bilim değildir elbet. Olsa olsa, bir meslek, sanat ya da felsefe olabilir. Gerçekleri arayıp sergileyen bir endüstri kolu, tarihten bir düzen yaratmaya çalışan bir sanat, bir dünya görüşü ve aydınlanma olanağı arayan bir felsefe! ...Bugün, ne yapacağımızı kestirmek için sarıp sakladığımız geçmiş; geçmiş ise, bugünü anlamak için açıp incelediğimiz hazinedir." 22 şeklinde söylediği sözlerden konuya daha çok felsefi açıdan yaklaşması neticesinde tarihin bugün için ne kadar önemli olduğunu bizlere vurgulamaya çalışmaktadır.

Tarihi bir araştırmanın sağlamlığı ancak bu vesikaların doğruluk derecesi ve bu vesikalara ulaşabilme sayesinde gerçekleşecektir. Halkın eserinde bu konuyu "Tarihi Vesikalar" başlığı altında işleyerek sözlü, yazılı, arkeolojik olmak üzere ayırdıktan sonra bu belgelere ulaşma yolları ile bu belgelerin korunma şekilleri üzerinde durarak şu açıklamayı yapmışır: " Kaynaklar, diplomatik kaynaklar ( kanunlar, resmi mektuplar vs..) ve nakli kaynaklar ( kronikler, hikayeler vs..) şeklinde alt gruplara ayrılır; ihmal edilmemesi gereken epigrafik kaynakları (kitabeler) da unutmamak gerekir." 23

Tosh eserinde yine aynı konu üzerine "Yazılı ve sözlü dil, coğrafi yüzey şekillerinin durumu ve insan yapımı maddi kalıntılar, güzel sanatlar ile fotoğraf ve film." olarak kısaca söz etmektedir ${ }^{24}$. Daha sonra Tosh tarihi kaynaklarla ilgili arkeolojik kalıntıları, kütüphaneleri, arşivleri, otobiyografileri, hatıraları, gazeteleri, resmi yayınları, parlamento konuşmalarını, özel mektupları, günlükleri, mahkeme ve diğer resmi kurum tutanaklarını, özel kayıtları, devlet kayıtlarını, kilise kayıtlarına da önemli bir yer vermiştir. Tarihi kaynakları birincil ve ikincil kaynaklar olmak üzere iki kategoriye ayırmıştır. Tarihi herhangi bir olayın içinde yer alan veya en yakın şekilde gazete ve dergide yayınlanması ile ilgili kaynakları birincil kaynaklar, olaydan daha sonra olay ile ilgili yazılıp çilen kaynaklara ise ikincil kaynaklar olarak adlandırmıştır.

Bernheim "Kaynak Bilgisi” altında olaya doğrudan karışmak veya şahit olmak ya da şahit olan veya karışan birinin bilgisine başvurma olarak verir. Burada haber, rivayet, ağız rivayetleri, ağızdan ağıza dolaşan veya birisinin olayı görmeden görmüş gibi anlatması (destan ve hikaye, efsane, menkıbe, fikra, manalı sözler, ata sözü) yer alır. Ayrıca yazı rivayetleri (tarihsel kitabeler, devlet adamları ile hükümdarların adlarını gösteren silsilename kılıklı cetveller, annal (yıllık yazılar) ve kronik (zaman yazıları, biyografi, hatıralar, gazeteler, açık mektuplar, beyannameler, resim haberleri) vardır. Bunun dışında bakiyeler (insanların kendi vücut bakiyeleri, dil ve etimoloji, adet, ahval, töre ve her türlü müesseseler, bütün sanat, sınat, protokol ve emsali evraklar), abideler (abideler ve kitabeler, dokümanları (vesika) gibi vesikalar da bulunur. ${ }^{25}$

\section{Laboratuar Yöntemine Safranbolu Örneği}

Safranbolu kenti Osmanlı Devleti'nin saray kültürünün küçük bir modelini oluşturmaktadır. Kentin taşınmaz ve taşınır eserleri laboratuar yöntemi ile incelendiğinde dönemin siyasi, sosyal, ekonomik ve kültürel yapısı ile ilgili ayrıntılı bilgiler elde edilebilmektedir. Kentin bu zengin kültür

${ }^{22}$ E. H. Carr, (1972), What is History?,Alfred A Knopf Inc, New York, s.146; W.-A.Durant; (1992), Tarihten Dersler, Çev. Bozkurt Güvenç, İstanbul 1992, s.14; Teo Grunberg, (1985), "Neopozitivizm’in Bilim Anlayışının Eleştirisi”, Bilim Kavramı Sempozyumu Bildirileri, Ankara Üni. Basımevi, Ankara, s.33-34.

${ }^{23}$ J. Tosh, a.g.e, s.20; Fernand Braudel, (1992), Tarih Üzerine Yazılar, İmge Yayınları, Ankara, s. 51, 107; Mübahat K. Kütükoğlu, (1994), Tarih Araştırmalarında Usûl, 3. Basım, Kubbealtı Neşriyatı, İstanbul, s. 3.

${ }^{24}$ J. Tosh, a.g.e, s.30; George G. Iggers, (2000), Yirminci Yüzyılda Tarih Yazımı, Tarih Vakfı Yurt Yayınları, İstanbul,s. 8; John Fontana, Edward H.Carr, (1992), Tarih Yazımında Nesnellik ve Yanlılı, İmge Yayınları, Ankara, s. 64.

${ }^{25}$ E. Bernheim, a.g.e, s.97-135; Keith Jenkins, (1997), Tarihi Yeniden Düşünmek, Dost Yayınları, Ankara, s. 43; Richard Evans, (1999), Tarihin Savunusu, İmge Yayınları, Ankara, s. 181; Zafer Toprak (1986), “Türkiye'de Çağdaş Tarihçilik (1908-1970)”, Türkiye'de Sosyal Bilim Araştırmalarının Gelişimi, Der: Sevil Atauz, Türk Sosyal Bilimler Derneği Yayını, Ankara, s. 433-434. 
yapısı nedeniyle 1994 yılında UNESCO tarafından “Dünya Kültür Miras Kenti” listesine alınmıştır. Kentin bu özelliği sonrasında kent ve çevresinde önemli ölçüde kültür varlığı koruma altına alınmıştır. Kent ve çevresinde kültür varlığı olarak eski çarşıda 1008, Yörük Köyü’nde 93 adet tarihi eser bulunmaktadır. Bu eserler arasında bir özel müze, yirmi beş cami, sekiz çeşme, beş hamam, üç han, bir tarihi saat kulesi, bir güneş saati ve tarihi değere sahip evler bulunmaktadır. Bunların yanında eski dönemlere ait höyük, köprü ve kaya mezarları da yer alır. ${ }^{26}$

Tablo 1: Safranbolu Nüfus Dağılımı ${ }^{27}$

\begin{tabular}{|l|l|l|l|l|l|l|l|}
\hline Yıl & Nüfus & Yıl & Nüfus & Yll & Nüfus & Yll & Nüfus \\
\hline 1890 & 7500 & 1945 & 5164 & 1965 & 9771 & 1985 & 22404 \\
\hline 1900 & 8000 & 1950 & 5388 & 1970 & 12468 & 1990 & 24351 \\
\hline 1935 & 5571 & 1955 & 6155 & 1975 & 14700 & 1997 & 31387 \\
\hline 1940 & 5327 & 1960 & 7352 & 1980 & 19440 & 2016 & 63965 \\
\hline
\end{tabular}

Kentin Osmanlı Devleti'nde ve daha sonra cumhuriyet döneminde doğal yapısını koruması ve hızlı değişime uğramaması nüfus artış hızında hızlı değişikliklerin olmayışına bağlıdır. Safranbolu'nun Tablo 1'de görüldüğü gibi nüfus artış hızında doğal bir nüfus planlaması gerçekleşmiştir. Kentte her ne kadar konak sayısı fazla ve her konakta önemli ölçüde oda sayısı bulunmasına rağmen çocuk sayısı devamlı sınırlı sayıda kalmıştır. Ailelerin genelde iki çocuğu bulunmaktayd1. Kentte daha fazla çocuk yerine, eğitimli çocuklara önem verilmiştir. Bu bilinç Safranbolulu aidat duygusunu ve tahsilli kişi sayısını oldukça arttırmıştır.

Tablo I' de görüldügü gibi Osmanlı Devleti'nde Trablusgarb Savaşı'ndan başlayarak Balkan savaşları, I.Dünya Savaşı ve Türk Kurtuluş Savaşı gerçekleştiğinden bu savaşlar kentte önemli ölçüde nüfus kaybına neden olmuştur. Kentin hemen yakınında Cumhuriyet Döneminde Karabük Demir Çelik İşletmeleri'nin kurulması ve ülkenin diğer bölgelerinden önemli ölçüde nüfusun bölgeye gelmesiyle Safranbolu'nun da nüfusu artmaya başlamıştır. Bu durum kentin iç durumu ile ilgili olmayıp dış etkenlere bağlı olarak gelişmiştir.

Safranbolu'da labaratuar yöntemi kullanılarak halkın yaşam alanlarının yer aldığı taşınmaz varlıklar araştırılmıştır. Taşınmaz kültür varlıkları arasında evler, çeşmeler, mezarlar, köyler, cami türbe, medrese, han ve hamam yer alır. Taşınmaz kültür varlıklarının yapıları, boyutları, işlevi, nicel ve nitel durumu kentin sosyal ve ekonomik durumu, kültür hayatı ve yaşamları hakkında bilgi vermektedir. Taşınır kültür varlıkları arasında kadın, erkek giysileri ve elsanatları örnekleri, ekonomik durum ile ilgili dericilik, yemenicilik, nalbantlık, semercilik, saraçlık, demircilik, bakırcılık ve dokumacılık gibi bazı meslek alanları incelenmiştir.

\subsection{Evler}

Safranbolu'yu ülkede ve dünyada ön plana çıkararak Dünya Miras Kenti olmasını sağlayan iyi korunarak bugünlere kadar gelen ve geleneksel Türk Mimarisinin özelliklerini taşıyan Safranbolu evleridir. Bu evler kentsel konumları ve mimarileriyle dikkate değerdirler. Safranbolu Evleri yüzlerce y1llık bir süreçte oluşan Türk kent kültürünün en önemli örnekleridir. Bu evler yörenin kültürü; aile yapısı, ekonomisi ve gelenekleri hakkında önemli bilgiler vermektedir. Safranbolu'da Hükümet Konağı'nın 1904 yılında Kastamonu Valisi Enis Paşa tarafından yaptırılmış olması mülki idare bakımından Safranbolu'nun Kastamonu vilayetine bağlı olduğunun göstergesidir.

\footnotetext{
${ }^{26}$ Karabük Valiliği, İl Kültür Müdürlüğü, (1999), Karabük İl Yıllığı ,s.200; TUİK, (2016), 2016 Yılı Nüfus Sayımı Verileri, Ankara.

${ }^{27}$ DİE, (1927), 1927 Yılı Genel Nüfus Sayımı Verileri, s.38-39. Verilere göre coğrafi bölgeler baz alınarak bu çalışma için oluşturulmuştur.
} 
Tablo 2'de Safranbolu'daki konaklardan bazılarının isimleri ve dönemleri yer almaktadır. Bu tablodan bu evlerin sahiplerinin kentte önemli aileleri oluşturduklarını ve kentin yönetiminde söz sahibi oldukları ortaya çıkmaktadır. Bu evler kentte daha sonraki birçok eve model olmuştur. Safranbolu evlerinin hepsi birbirinin güneşini kapatmamakta ve yolu bulunmaktadır. Sokaklar Arnavut kaldırımı ile döşenmiş ve iki yüklü hayvanın yan yana geçebileceği kadar geniş sokaklar yapılmıştır. Evler iki katlı olup zemin kat taştan, üst katlat ahşap yapıdan oluşan, alt katta az, üst katta daha fazla pencere ve çıkma bulunmaktadır. Çıkmalar payandalarla desteklenmişlerdir. Evin kısımları arasında; zemin kat, sokak kapısı, hayat, kazan ocağı, ahır, samanlık, odalar, oda girişi, oda kapısı, pencere duvarı, yer, sofa, sış sofalar, köşe sofaları, orta sofalar yer almaktadır. ${ }^{28}$

Tablo 2: Birkaç Safranbolu Evi Örneği

\begin{tabular}{|l|l|l|}
\hline Kültür Mirasısının Türü & Dönemi & Yaptıran \\
\hline Kaymakamlar Evi & $18-19$. Yüzyıl & Hacı Mehmet Efendi \\
\hline Mümtazlar Konağı & 1888 & Müderessis Ziya Eefendi \\
\hline Kavsalar Evi & 19. Yüzyı1 & Damaklığlu Hacı Ahmet Efendi \\
\hline Karaüzümler Evi & 19. Yüzyıl & Mehmet Karaüzüm \\
\hline Kilerciler Evi & 1884 & Hacı Mehmet Efendi \\
\hline
\end{tabular}

Kent merkezinde 18 ve 19.Yüzyıl ile 20.Yüzyıl başlarında yapılmış yaklaşık 2000 geleneksel Türk evi bulunmaktadır. Bu eserlerin 800 kadarı yasal koruma altındadır. Evler Safranbolu'nun iki ayrı kesiminde gruplanmış durumdadır. Evlerin büyüklüğü, düzgün ve sağlam yapılışı, iç düzenlemelerinin zenginliği, geniş olmaları, bol meyveli bahçelerinin olması, içinde havuzu bulunması, halkın yazlık kışlık ayrı konaklarının bulunması kültür düzeylerinin oldukça yüksek olduğunu gösterir. Evin ilk katında hayat bulunur ve ortak kullanılır. Yemek, bulaşık, çamaşır ve 1sınma gibi konular ortak olmasına karşın her çiftin evde ayrı bir odası, odada gusülhane, soba, yemek için düzeneği bulunmaktadır. Bu odalar Türk kültürünün mahremiyetini sağlar, tamamen Türk kültürüne göre döşenmiştir; danteller, sedirler, yanlık halıları, halılar, yüklük, tahta kaşıklar bunların bazılarıdır. Odalarda yer yataklarında yatılır ve yemekler yerde yenirdi. Safranbolu evleri 18 ve 19.yüzyıl Türk toplumunun geleneksel yaşam kültürünü, ekonomisini en iyi şekilde yansıtmaktadır. ${ }^{29}$

Safranbolu halkının sosyo ekonomik durumu yaşantısına da yansımıştır. Genellikle halk ataerkil aileye, Türk örf ve adetlerine göre yaşantısını sürdürmüş, tek kapta yemek ve tek elden yönetim, iş paylaşımı yapıldığı, çok odalı, iki katlı konak türü evlerde yaşamalarını sürdürmüşlerdir. Safranbolu evleri Osmanlı Mimarisini yansıtmaktadır. Evlerin bu denli büyük olması Türklerin ataerkil aile yapısı nedeniyle kalabalık oluşlarındandır. Tüm aile üç kuşak bu evde yaşamlarını sürdürmektedirler. Bölge'de coğrafi şartların tarım kültürü ile bağdaştırılması ile hem kışlık hem de yazlık konaklara sahip olmuşlardır. ${ }^{30}$

\section{2. Çeşmeler}

Su hayattır, su olmadan canlı ve hayvanların yaşaması mümkün değildir. Safranbolu'nun bir yerleşim yeri olmasının en önemli özelliklerinden biri suyunun bol olmasıdır. Bizans döneminden kalma yöredeki en önemli yapı unsuru kuşkusuz, 116 metre uzunluğundaki İncekaya Su Kemeri'dir. Bu kemerden Safranbolu'ya 7,5 Km. mesafeden künklerle su getirilmiştir. Bu su kemeri 18. Yüzyılın

\footnotetext{
${ }^{28}$ Zeynep Oral, (1976), "Türk tipi evlerin tüm özelliklerini taşıyan Safranbolu evlerinin korunması Zorunludur”, Milliyet Sanat Dergisi, 26 Kasım; Bülent Çetinor, (1976), "Safranbolu Evleri”, Illgi Dergisi, Mayıs Sayısı.

${ }^{29}$ Engin Karadeniz, (1975), "Safranbolu Mimari Değerleri ve Folkloru Haftası Bugün Başlıyor”, Cumhuriyet, 30 Ağustos; Doğan Kuban, (1976), "Safranbolu Olayı”, Cumhuriyet Gazetesi, 2 Eylül.

${ }^{30}$ Vedat Nedim Tör, (1977), "Safranbolu'daki Evlerin Dersleri,” Milliyet 13 Mart; Turgut Cansever,(1992), Şehir ve Mimari, İstanbul, s.25; Ünsal Tunçözgür,(2002), Dünü ve Bu Günü ile Safranbolu, Işıl Yayınc1lık Safranbolu, s.48.
} 
sonlarına doğru III. Selim'in Sadrazamı İzzet Mehmet Paşa tarafindan yeniden onarılmış ve Safranbolu'nun su ihtiyacı giderilmeye çalışılmıştır. ${ }^{31}$

Tablo 3: Safranbolu'da Çeşmeler

\begin{tabular}{|l|l|l|}
\hline Köprülü Çeşmesi, Hicri 1070 & Yzb. İsmail Ağa Çeşmesi, 1890 & Hamide Hatun Çeşmesi, 1819 \\
\hline Hac1 Abdullah Ağa Çesmesi, Hicri 1287 & Hidayetzade Çeşmesi, 1803 & Tuzcupnarı Çeşmesi, 1811 \\
\hline $\begin{array}{l}\text { Kuru Beyzade Ali Efendi Çeşmesi Hicri } \\
1197\end{array}$ & Paşapınarı Çeşmesi, 1794 & Alibey Çeşmesi (1782) \\
\hline $\begin{array}{l}\text { Antepzade Hacı Mehmet Ağa Çeşmesi, } \\
1811 .\end{array}$ & Salih Paşa (Kilci) Çeşmesi, 1818 & Taş Minare Ceşmesi, 1692 \\
\hline Mescit Çesmesi, 1905 & Köprübaşı Çeşmesi, 1838 & Ala Bekir Çeşmesi, 1848 \\
\hline Hidayetullah Çeşmesi, Hicri 1218 & Hacı Hafız Çeşmesi, 1844 & Çuhadar Çeşmesi, 1850 \\
\hline Kayıkçı Çeşmesi & Kamil Efendi Çeşmesi, 1864 & Fatma Hanım Çeşmesi, 1862 \\
\hline Emir Hocazade Çeşmesi & Karakullukçu Çeşmesi, 1874 & Sadullah Çeşmesi, 1871 \\
\hline Numan Ağa Çeşmesi, 1906 & Kileci Çeşmesi, 1903 & Kadıfendi Çeşmesi, 1896 \\
\hline Cilbir Çeşmesi,1889 & Hamidiye Çeşmesi, 1905 & Fatma Hanım Çeşmesi, 1905 \\
\hline Paşa Suyu 1798 & Çatalpınarı Çeşmesi (1833) & \\
\hline
\end{tabular}

Tablo 3’te Safranbolu'daki çeşmelerin bazıları yer almaktadır. Bu çeşmeleri kentin ileri gelen ve varlıklı aileleri yaptırdığı çeşmelerin isminden anlaşılmaktadır. Çeşmeler tarihlerine göre daha çok Osmanlı Devleti'nin son yüzyılında yapılmıştır. Buna göre toplumun su ihtiyacı devletten ziyade halk tarafından karşılanmaya çalışılmaktadır. İslam ve geleneksel Türk kültüründe su önemli bir yere sahiptir. Toplumda varlıklı kişilerin geride bir eser bırakıp hayırlarının devam edebilmesi için çeşme yaptırması önemli bir gelenektir. Çeşmelerin genellikle üzerinde bir kitabe bulunmaktadır. Bu kitabelerde çeşmenin kim tarafından ve ne amaçla yaptırıldığı, yaptırılış tarihi ve İslam Dini'ne göre "Ruhuna Fatiha" ibareleri yer almaktadır. Bazı çeşmelerde ise bir dörtlük şiir veya manzume yer almaktadır. ${ }^{32}$

Safranbolu'nun her sokağının başında mutlaka bir çeşme olduğu görülmektedir. Bu çeşmeler geleneksel Türk ve İslam kültürüne göre ölen kimseleri aileleri veya sağken bazı varlıklı kişileri veya Osmanlı'da çok ayrıcalıklı sosyal bir yeri olan vakıflar tarafından yapılmışlardır. Safranbolu'da sadece sokaklardaki çeşmeleri dolaşmakla bile kent kültürü ve tarihi hakkında fikir edinilebilmektedir. Safranbolu'da taşınmaz kültür varlığı tescilli 93 çeşme bulunmaktadır. ${ }^{33}$

Safranbolu'da gerek kentin ve gerekse çevre köylerin ekmek ihtiyacını karşılamak üzere su ile çalışan 5 adet değirmen yer alır. Bu değirmenler yaşamın önemli bir özelliğini oluşturur.

\subsection{Mezarlar}

Taşınmaz kültür varlıkları arasında yer alan mezar taşları da geçmişi aydınlatan eserlerdendir. Mezar kitabeleri bölgenin sosyal, ekonomik, kültürel tarihini incelemede önemli bilgiler vermektedir. Karabük çevresinde Safranbolu'da 90, Bulak'ta iki, Yazıköy'de 44, Yörük Köyü’nde

\footnotetext{
${ }^{31}$ Kızıltan Ulukavak, (2003), Kentin Tarihi ve Mimari Değerleri, Türkiye'de Mimarlık Değerlerinin Korunmasinda Ilk Adımlar, Güven Ofset, Karabük, s.48.

${ }^{32}$ Metin Sözen, (2003), Safranbolu ve Anttları Konusunda Kisa Bilgiler, Kentin Tarihi ve Mimari Değerleri, Türkiye'de Mimarlık Değerlerinin Korunmasında İlk Adımlar, Güven Ofset, Karabük.

${ }^{33}$ Zeki Erginsu, (1975), Avrupa Mimari Mirası Y1lı 1975 Kampanyası münasebetiyle Safranbolu Mimari Değerleri ve Folkloru Haftası ve Sorunları, İktisat Dergisi, Eylül, Sayı 133.
} 
27, Konarı Köyü'nde 11 ve Hacılarobası Köyü'nde 47 adet Osmanlıca kitabesi bulunan mezar yer almaktadır. Hacılarobası Köyü'ne ilk yerleşim Romalılar dönemine aittir. Köy yakınlarında Roma dönemine ait "Kaya Mezarları" bulunmaktadır. Kaya mezarları bir bölgeyle sınırlı olmayıp dağınık haldedirler. Bunlardan yedi tanesi köyün merkezindeki Örencevizi mevkiinde olup şimdiye kadar dördü açılmış üçü ise henüz açılmamıştır. Köy yakınlarında Yassı Bakacak Mağarası Kaya Mezarı, Tütünlük İni Kaya Mezarı, Çukurköy Mağarası Kaya Mezarı, Karakoyunlu Mahallesi Kaya Mezarları (Karakoyunlu Mağarası Kaya Mezarı ve Kral Mezarı) bulunmaktadır. Kral Mezarı karşısında bulunan iki yüksek kayanın ismi "Kurutma Kayası" olup kralın cezalandırdığı kişileri buraya çıkartarak aç, susuz bıraktırır ve cezalı sonunda atlayarak intihar edermiş. Köyde dokuz kaya mezarı, bir deliktaş ve bir mezar odası bulunmaktadır. ${ }^{34}$

Mezarların kitabeleri önemli bilgileri içermektedir. Öncelikle kitabenin şekli kişinin ekonomik durumu ile ilgili bilgi vermektedir. Daha sonra kişinin doğumu, ölümü, ölüm nedeni ve mesleği ile de ilgili bilgileri içermektedir. 18. ve 19. yüzyılda İstanbul'da ekmekçilik, börekçilik, simitçilik ve unlu mamullerle uğraşan köylülerin köyde yaptırdıkları konak ve mezar taşlarından durumlarının oldukça iyi olduğu anlaşılmaktadır. Bazı kitabeler üzerinde İslam Dini ile ilgili önemli deyiş ve dualar ile halk edebiyatı ile ilgili dörtlük veya manzumeler yer almaktadır. ${ }^{35}$

Yörük Köyü mezarlığında Osmanlıca okunabilir kitabesi olan 47 adet mezar taşı vardır, fakat yedi tanesinin taşı kırık durumdadır. Bu mezarlardan 20 âdetinin kitabeli baş taşı, 20 âdetinin hem baş taşı kitabeli, hem de işlemeli ayak taşları, bir âdetinde sadece işlemeli ayak taşı, üç âdetinde ise ayak ve baş taşı olmayıp gövde bölgesinde kitabe, iki tane lahit gövdesi kabartmalı işlenmiş şekilde yer almaktadır. Mezarlığın yaklaşık 500 metre yakınında Bektaşi Hacı İsmail Efendi’nin türbe mezarı bulunmaktadır. ${ }^{36}$

Yörük Köyü mezarlığındaki okunabilir ilk kitabe Hicri 1208 yılına aittir. Yörük Köyü, Hacılarobası ve Yazıköy'ün mezarlıkları köyün girişinde yer almıştır. Köye giriş yolu mezarlığın ortasından geçmektedir. Yörük Köyü'nün köye giriş yolunun her iki kenarında yer alan kitabeler "Hacı Bektaşi Veli" ve "Hu Dost" ibareleriyle başlamaktadır. Köyün kurucularının mezarlı̆̆ı bu yerde oluşturmalarının nedenini köyde yaşayanların veya köye gelip gidenlerin mezarlıktan geçerken ölmüşleri için bir Fatiha okumasını istemiş olmalarıdır. Bunun yanında mezarlık bir kimsenin bu dünyaya fazla itibar etmemesi gerektiği, mutlaka her canlının öleceği, zenginlerin dahi buraya mallarını götüremediğinin unutulmaması gerektiğini hatırlatmaktadır. Mezarlık kişiye kimseyi kırmamayı, günah işlememeyi, insanlarla iyi geçinmeyi ve insanların çalışması gerektiği gibi konularda ders vermektedir. Yörük Köyü'nde mezarlığın ortasında "suluk" diye anılan 3x3 metre ebadında bir yapı bulunmaktadır. Bu yapı içerisinde bir su deposu ile oturma yerleri yer almaktadır. Buna göre halkın mezarları temiz tutması, sulamas1, bakımını yapmas1 ve zaman zaman buraya gelerek oturup vakit geçirmesi planlanmıştır. ${ }^{37}$

\subsection{Köyler}

16. yüzyılda Safranbolu çevresinde yaşayan göçebe topluluklara "Yörükan-1 Taraklı" veya "Yörükan-ı Taraklıborlu" ismi verilmektedir. Osmanlı döneminde iki ayrı kaza vardır, bunlardan biri Safranbolu merkezindeki "Medine-i Taraklıborlu", diğeri ise "Yörükkan-1 Taraklıborlu" adıyla bugünkü Yörük Köyüdür. Yörük Köyünün geçmişi 14 ve 15.yüzyıllarda konargöçer durumda olan

\footnotetext{
${ }^{34}$ Yavuz İnce,(1975), Kentlerin Tarihsel Dokusunun Korunmasında Yerel Örgütlerin Kurulması ve Bölgesel Eğitim Birimlerinin Oluşturulması, ITÜ̈ MTRE Bülteni, Sayı 4, İstanbul.

${ }^{35}$ Servet Gürsel, (1976), "Safranbolu'da Etnik Yapı ve Kültür Değişimleri”, MTRE Bülteni, S.5-6,C.2.

${ }^{36}$ Kızıltan Ulukavak, (1976), "Safranbolu Kentinin Mimari Değerlerinin Korunması, Sorunları ve Safranbolu Belediyesi", MTRE Bülteni, S.5-6, C.2.

${ }^{37}$ Feridun Akozan, (1976), “Geçmişimiz İçin Gelecek”, Kültür ve Sanat Dergisi, Haziran.
} 
Karakeçili aşiretine bağlı oymaklar ve Taraklı aşireti mensupları oldukları sanılmaktadır. Bu köydeki Eğmür, Akyazı, Çatak gibi geleneksel Türk oymak isimlerinden bu kanıya varılmaktadır. Yazıköy, Yörük, Akören, Hacılar Obası, Üçbölük köyleri Safranbolu'ya benzer tarihi dokularıyla ilgi çekmektedir. Safranbolu'ya bağl1 "Yörük Köyü” bir Türkmen köyü olarak yer alır ve köyde 93 adet yapı bulunmaktadır. Yörük Köyü Osmanlı dönemine ait geleneksel ev mimarisinin en güzide örneklerini teşkil eder.

\subsection{Cami, Türbe, Medrese, Han ve Hamamlar}

Tablo 4'te taşınmaz kültür varlıkları arasında yer alan diğer eserler bulunmaktadır. Yörede İslam kültürünü en iyi yansıtan unsurlardan biri olarak camiler yer almaktadır. Bu camiler kimin tarafindan yaptırıldığ 1 , yaptırılan tarih, döneminin ekonomik, kültürel, sanatsal ve siyasi yönü konusunda önemli bilgiler vermektedir. Yörede İslam Dini ile ilgili diğer önemli unsurlardan olan türbe, medrese ve tekkeler de bulunmaktadır. Medreselerin yer alması yörede eğitime önem verildiğinin göstergesidir. Yörede önemli tekkeler yer almıştır. Bu tekkeler yörenin ahilik teşkilatının oluşturulması ve yörede ekonomik canlılığın yapılandırılmasında etkin olmuştur. 14. yüzyılda Candaroğlu Süleyman Paşa Medresesi yer almaktadır. Safranbolu'nun kültür hayatında yer alan diğer bir eğitim kurumu tekkelerdir. Nakşibendi Tarikatının Kalealtı Tekkesi, Haydar Ağa Tekkesi, Halveti Tarikatı'nın Ali Baba Tekkesi bunlardan bazılarıdır . ${ }^{38}$

Safranbolu'da 1888 yılında Frengi Hastanesi yapılır ve daha sonraki y1llarda Devlet Hastanesine dönüştürülür. Bu hastane o zamanlar ülkedeki beş zührevi hastaneden birini oluşturmaktadır. Buna göre bölgede zührevi hastalıkların yaygın olduğu ve yörede ahlaki durum dışında ilişkilerin yaşandığını göstermektedir. Bu tür ilişkilerin önüne geçebilmek ve ortaya çıkan hastalıklarla mücadele ederek zürriyetin devam edebilmesini sağlamak amaç edinilmiştir. ${ }^{39}$

Tablo 4: Safranbolu'da Türbe, Medres, Tekke, Han, Hamam, Hastane, Saat Kulesi, Su Kemeri ve Cezaevi.

\begin{tabular}{|l|l|l|}
\hline Camii & Türbe, Medrese ve Tekke & $\begin{array}{l}\text { Han, Hamam, Hastane, } \\
\text { Saat Kulesi, Su Kemeri ve } \\
\text { Cezaevi }\end{array}$ \\
\hline Köprülü Mehmet Paşa Camii, 1661 & Hasan Paşa Türbesi, 1845 & Cinci Hanı ,1645 \\
\hline Hidayetullah Camii, 1693 & Gazi S.Paşa Medresesi, 1846 & Yeni Hamam, 1645 \\
\hline Dağdelen Camii, 1767 & $\begin{array}{l}\text { Şeyh Mehmet Efendi } \\
\text { Türbesi, 1871 }\end{array}$ & Saat Kulesi, 1796 \\
\hline Kazdağlı Camii, 1778 & $\begin{array}{l}\text { Ali-Hasan Baba Türbeleri, } \\
1872\end{array}$ & Cezaevi, 1906 \\
\hline İzzet M.Paşa Camii, 1796 & $\begin{array}{l}\text { Candaroğlu Süleyman Paşa } \\
\text { Medresesi 14.Yüzyıl }\end{array}$ & Frengi Hastanesi, 1888 \\
\hline Kaçak (Lütfiye) Camii, 1879 & Kalealtı Tekkesi ,1550 & İncekaya Su Kemeri \\
\hline Hamidiye Camii ,1884 & Haydar Ağa Tekkesi & \\
\hline Köyiçi Camii , 1908 & Ali Baba Tekkesi , 1824 & \\
\hline Kalealtı Tekkesi Camii 1950 & \multicolumn{2}{l}{} \\
\hline
\end{tabular}

Safranbolu'da hanların bulunması yörenin bir ulaşım güzergâhı üzerinde olduğunu göstermektedir. İstanbul-Bolu-Amasya-Tokat-Sivas Kervanyolunu Sinop'a bağlayan yol GeredeSafranbolu-Kastamonu-Sinop Yolu üzerinde olması nedeniyle önemli bir konaklama merkezi olmuştur. Eski çarşıda bulunan Cinci Hanı bu nedenle yapılmıştır. Yörenin yol güzergâhı üzerinde

\footnotetext{
${ }^{38}$ Reha Günay, (1998), s.98-99.

${ }^{39}$ Kızıltan Ulukavak, (1976), Safranbolu Kentinin Mimari Değerlerinin Korunması, Sorunları ve Safranbolu
} Belediyesi, MTRE Bülteni, S.5-6,C.2. 
olması ekonomisi ve ticareti üzerinde de etkili olmuştur. Yörede su ve temizlik kültürünün gelişmiş olmasının bir göstergesi de hamamlardır. Hamamlar yörede konaklayanların yanında yöre halkına da hizmet etmektedir. Hamam kültürü geleneksel Türk kültürü ve İslam dininde önemli bir yere sahiptir. Hamam kültürüne göre haftada bir defa hamama gidilerek yıkanır. Erkeklerin yanında haftada bir defa kadınlar da topluca hamama giderek hem yıkanır, hem de eğlenir.

\subsection{Kadın, Erkek Giysileri ve EI Sanatları}

Taşınır kültür mirasları arasında tarihi süreç içerisinde bölgede giyilene kadın ve erkek giysileri önemli bir yer tutmaktadır. Giysilerin cinsi ve kalitesinden yörenin ticari, ekonomik ve kültür yapısı hakkında bilgi edinilmektedir. Türk gelenek ve göreneklerini ortaya koyan bu giysiler özellikleri ile beraber yaşatılarak gelecek kuşaklara aktarılması sağlanmalıdır.

Tablo 5: Safranbolu’da Kadın- Erkek Giysileri, Kadın Süs Eşyaları, El Sanatları.

\begin{tabular}{|l|l|}
\hline Kadın giysileri & $\begin{array}{l}\text { tefebaş-bindallı, fistan (uzun entari), pamuklu entari, uzun pazen don (setüklü), şetari } \\
\text { (ipekli kadife kumaş), hürriyet yünlüsü, sırmalı kadife, oyalı yazma, sırmalı çarşaf- } \\
\text { cibinlik, simli çevre, içli-dışlı kundura, sümsüm mes, sim içli bohça, zelgerde. }\end{array}$ \\
\hline $\begin{array}{l}\text { Kadın } \\
\text { süseşyaları }\end{array}$ & gümüş kemer, ön zinciri, toka, enteşe (kalın altın bilezik). \\
\hline Erkek giysileri & $\begin{array}{l}\text { bürümcek göynek, uzundon, simli ve ipek uçkur, yün kuşak, fes, sarık, mes lastik, } \\
\text { kalın yünlü elbise, pamuklu yün göynek, seymen kıyafeti, lorta, ürüzger, uluayak, } \\
\text { yemeni, çarık, köstekli saat, tabaka, ağızlık, tesbih. }\end{array}$ \\
\hline El Sanatları & $\begin{array}{l}\text { Delik işleri, kaneviçe işleri, sırma işleri, telli işler, simli Türk işi dantel (oya ve } \\
\text { yazma), kıl dokumacılığı (harar, kıl heybe, çuval, kebre), ahşab işleri. }\end{array}$ \\
\hline
\end{tabular}

Safranbolu'daki el sanatları daha çok bölgede hayvancılı̆̆ın, ticaretin ve sanatın gelişmiş olduğunu göstermektedir. Safranbolu'da kadınlar konaklarda boş vakitlerini el sanatları ile değerlendirmektedirler. Safranbolu halkı daha çok sanat ve ticaretle uğraşmakta, kenar köyler ormancılık, hayvancılık ve tarımla uğraşmaktadırlar. Pazar Safranbolu'da kurulduğundan mallar burada satın alınmakta ve kadınlar tarafından el sanatları olarak tekrar değerlendirilmektedir; delik işleri, kaneviçe işleri, sırma işleri, telli işler, simli Türk işi dantel (oya ve yazma), kıl dokumacılığı (harar, kıl heybe, çuval, kebre), ahşab işleri gibi. ${ }^{40}$

\subsection{Lonca Sistemi}

Safranbolu'da üretim ve ticaret "lonca" sistemi ile yürütülür. Bu sistemin temeli üretim ve ticaret dallarının kendi aralarında ayrı ayrı olarak ve birer meslek kuruluşu şeklinde örgütlenmeleridir. Loncalar günümüzdeki meslek odalarının karşıllı̆ı olup çok sağlam ve sistematik bir yapıya sahiptirler. Yemeniciler Loncas1, Demirciler Loncas1, Bakırcılar Loncası gibi. Bu sistem Osmanlı Devleti'nde Tanzimat'a kadar devam etmiştir. Tanzimat'tan sonra ismi "Gedik Teşkilatı" olarak değiştirilmiş ve Cumhuriyet'in başına kadar devam etmiştir. 1924 yılında Safranbolu Ticaret Odası'nca yayınlanan bir risalede meslek adları, sayıları ve kaç kişi çalıştırdıkları yer almaktadır. ${ }^{41}$

Safranbolu ekonomik ve sosyal yapısı ile çevresinde bir pazar yeri konumundadır. Çevredeki köyler ürettiklerini buraya getirerek satarlar ve buradan ihtiyaçlarını alırlardı. Bölgenin özelliklerine ve ihtiyaçlarına göre Safranbolu'da meslek grupları oluşmuştur. Bu nedenle bu meslek grupları incelenerek yörenin iktisadi, ekonomik ve ticari yapısı hakkında bilgi edinilebilir.

\footnotetext{
${ }^{40}$ Doğan Kuban, (1966), “Anadolu- Türk Şehri Gelişmesi, Sosyal ve Fiziki Özellikleri Üzerine Bazı Gelişmeler”, Vakıflar Dergisi, Sayı VIII, İstanbul.

${ }^{41}$ Hulusi Yazıcıŏu, (1982), Safranbolu, Karabük Özer Matbaası, s.45-60.
} 


\subsubsection{Deri ve Yemeni}

Safranbolu'nun en önemli üretimini deri ve deri eşyaları oluşturur. Mordtmann 1852 y1lında buradaki dericiliğin oldukça önemli olduğunu belirtmektedir. 1924 yılında Safranbolu Ticaret ve Sanayi Odasının yayınladığı kitapta 100'e yakın tabakhanede 415 işçi çalışmaktadır. Bunun yanında yemenici, kunduracı, dikici olarak 430 kişi, deri ile uğraşan 16, yemeni, kundura, kavafiye ticareti ile uğraşan 5 tacir bulunmaktadır. 1970'li yıllarda yemeni diken dükkân sahibi dikiciler de arasta denilen çarşıda 46 dükkânda toplanmıştır. 1975 yılında sadece iki yemenici dükkânı kalır. 1990 yılında Ahmet Demir Özen'in ölümü ile dükkânı müze haline getirilmiştir. ${ }^{42}$

Safranbolu'nun Amasra ve Bartın limanlarına yakın olması ve buradan deniz yolu ile İstanbul'a ulaşım sağlandığından Safranbolu'da dericilik önemli ölçüde gelişmiştir. Yöredeki Yörük kültürünün olması ve hayvancıllğın Yörüklerin temel geçim kaynağını oluşturması yörede dericiliğin ileri gitmesinin nedenleri arasındadır.

\subsubsection{Nalbant, Semerci ve Saraç}

Türklerin hayvancılıkla uğraşması ve uzunca süre göç etmesi ile bu meslekler günlük hayatta oldukça önemli bir yer tutar. Zira Türklerde ulaşım, tarım ve yük taşımacıllı̆ında kullanılan binek hayvanları için bu meslekler çok önemlidir. Safranbolu çevresindeki köylerin ulaşımında hayvanlar kullanıldığından nalbantlık, semercilik ve saraçlık oldukça önemli bir yer oluşturmaktadır. Semerci ustası M. Kemal Ağyaroğlu'na göre Safranbolu'da 40-50 sene önceleri 15-20 semerci olmasına karşın şimdilerde sadece üç adet semerci vardır. O’na göre bu mesleğin en büyük probleminin öğrenilmesi için ortamın bulunmaması olduğu ve sadece turizme yönelik çalışıldığ 1 ve bu nedenle turizmin bu mesleğin devam etmesinin en büyük nedenidir. Saraç ustası Hüsnü Yıldırım da Safranbolu'da önceleri 20'ye yakın saraç varken artık iki adet kaldığını, bu hayvancılığın eskisi kadar yapılmadığı ve mesleğe kimsenin ilgi göstermemesinden kaynaklandığını, kendisinin de turizm sayesinde mesleğini devam ettirdiğini ifade etmektedir. ${ }^{43}$

\subsubsection{Demircilik ve bakırcılık}

Türklerde çok eskiden beri çok önemli bir yer tutan demircilik mesleği Safranbolu'da da gelişmiştir. Türkler esasen Ergenekon'dan çıkış destanı ile beraber her zaman demirle beraber olmuşlar ve adeta demirle özdeşleşmişlerdir. Demir Türklerde sağlamlık, kudret ve dayanıklılığı temsil etmektedir. Demirci ustası Hüseyin Demir demircilik ve kalaycılığın Safranbolu'da 207 sene önce başladığını, genellikle yapı malzemeleri, kapı kilidi, menteşe, tarım aletleri ve kap kaçak üretilmiş olduğunu ve bunların birçoğunun günümüzde de üretildiğini, çoğunun ise restore edilen yapılarda kullanıldığını ifade etmektedir. Yine Hüseyin Usta, artık eskisi gibi kap satılmadığı ve kalaycılığın da yapılmadığını ve bu mesleklerin devletçe koruma altına alınmazsa zaman içerisinde tamamen kaybolacağını söylemektedir. Eskiden kapların oldukça önemli bir bölümü bakırdan oluştuğundan bakırcılık mesleği ile bu kapların kullanılabilir hale gelmesi için kalaycılık mesleği oldukça gelişmiştir. ${ }^{44}$

\subsubsection{Dokumacilık}

Dokumacılık Safranbolu'da oldukça gelişmiştir. Daha çok dokumacılık evlerde el tezgâhlarında yapılır. Dokumacılık Türklerin geleneksel mesleğidir. Daha çok hayvancılıkla uğraştıklarından hayvanın her türlü kısmından yararlanmayı bilmişlerdir. Gök Bez: ticaret değeri olan kalın bezdir, genellikle tacire satılır, tacir boyatır ve mavi boyalı olanlardan köylüler erkek

\footnotetext{
${ }^{42}$ Kani Kuzucular, (1976), Safranbolu Çarşısı, Türkiye Turing ve Otomobil Kurumu Belleteni, S.54/333, TemmuzAğustos.

${ }^{43}$ Karabük İl Yıllı̆̆l, (1999), s.1156-160.

${ }^{44}$ Aytekin Kuş, Muammer Aksoy, (1992), Müze Kent Safranbolu, Kasım, Karabük, s.75.
} 
pantolonu yaparlar. Çite bezi: üzerine çeşitli desenlerde baskı yapılan bezlerdir. Kadınlar bu bezden dizlik denilen şalvar, yatak yüzü, bohça yaparlar. Tacir satın aldığı ince bezin üzerine baskı yaptırarak sofra bezi, karakalem yazdırarak yazma, başörtüsü yaptırarak satarlar. Alaca: yollu dokunan beze denir, döşemelik olarak ta kullanılır. Keçecilik: Geleneksel Türk kültürünün bir örneğidir, daha çok koyun yününden evde veya dükkânlarda yapılır. 1923'te on keçeci bulunmaktadir. ${ }^{45}$

\section{Sonuç}

19.Yüzyılda Avrupa'da köylü, burjuva, ruhban sınıfı ve aristokrasi arasındaki geleneksel yapı hürriyet ve bağımsızlık düşüncesinin hızla yayılmaya başlaması sonucu oldukça örselenmiştir. Bu süreç beraberinde Fransız İhtilali’ni getirmiş ve toplumda büyük bir değişiklik başlamıştır. Toplum düzeninde yaşanan bu farklılaşma bilim adamlarını yeni arayışlara yönlendirmiştir. Bu zamana kadar doğa bilimlerinin büyük ilerlemeler kaydetmesi, deneylerle gerçekliğe ulaşılabileceği düşüncesinin oluşması ve endüstri devrimi ne yazık ki toplumsal düzeni ve huzuru sağlamada yeterli olamamıştır. İşte bu noktada bilim adamları tarihe ve sosyal bilimlere pek itibar etmezken birdenbire bu bilimlerin sosyal düzeni kurmada son derece önemli olduğu görüşü ortaya çıkmıştır.

20.yüzyılın ilk yarısında dünya iki büyük savaş yaşamış ve birçok insanını kaybetmiştir. Bu sonuç bilim adamları arasında artık tarih biliminin tam olarak görevini yerine getiremediği düşüncesini doğurmuştur. $\mathrm{Bu}$ zamana kadar tarihin geçmişi incelediği ve geçmişi incelemenin günümüzü şekillendirmede rehberlik yapacağı yolunda idi, fakat geçmiş her iki dünya savaşını da engelleyememişti. $\mathrm{Bu}$ nedenle bilim adamları sosyal bilimler çatısı altında üst bir yapılanmaya gitme çalışması içine girmişlerdir.

20.yüzyılda sosyal bilimciler kendilerinden farklı kültür ve medeniyetleri incelemeye başlamışlardır. Bir kültürü incelemek için tarih metodolojisi içerinde Laboratuar Yöntemi gelişmiştir. Bu yöntemde tarihin sadece siyasi olaylarla ilgili olmayıp belirli bir coğrafyanın belirli bir zaman sürecinde tarihi, sosyal, ekonomik, kültürel bütün yönleriyle incelenmesi öne çıkmıştır. İşte bu laboratuar yöntemiyle Safranbolu incelenmiştir. 20. yüzyıl başlarında Safranbolu mimari özellikleri, caddeler, evleri, ibadethaneleri, kültürel varlıkları, yaşantısı, sosyal ve ekonomik yönü ile tam bir Osmanlı kenti görünümündedir. Kentte geleneksel Türk örf, adet ve gelenekleri aynen uygulanmaktadır. Kentte ticaret, el sanatlarının, tabakhane ve kereste ticareti gelişmiştir. Bu dönemde Safranbolu kendi kendine yetebilen, dışarıdan gaz yağı vb. dışında ihtiyacı olmayan ve devamlı diğer kentlere ihraç eden bir kent konumundadir.

Kent Bartın limanı nedeniyle deniz ulaşımına da sahiptir. Safranbolu'nun çevresinde tarım ve hayvancılık gelişmiş olduğundan genellikle çevre köyler ürünlerini ve emeklerini Safranbolu pazarına getirerek değerlendirmişlerdir. Üretim ve ticaret lonca sistemi içerisinde birbirlerini denetleyerek desteklemiştir. Safranbolu çevresindeki köylerle ekonomik ve ticari işbirliği içerisinde olmuş ve karşılıklı olarak üretim ilişkileri içerisine girmişlerdir. Yöre halkı geçimlerini çok rahat bir şekilde refah içerisinde sürdürmüştür. Aile yapısı, çocuk sayısı, konak yaşamı, su kültürü, insanların birbirlerine karşı hoşgörü ve anlayışı oldukça yüksektir. Evlerin yapılış nizamı, çeşmelerin uzaklıkları, su kanalları, hamam kültürü, bahçe duvarlarının durumu, Pazar yerleri oldukça muntazam, iletişime açık şekildedir. ,Bu nedenle sosyo ekonomik açıdan döneminde diğer kentlere göre oldukça ileri durumdadır.

$\mathrm{Bu}$ çalışmada daha sonra herhangi bir yörenin derinlemesine değil belirli bir zaman diliminde tüm yönleriyle incelenmesine bir örnek oluşturmaktadır. Araştırmacılar artın bütünü değil parçayı en ayrıntılıca inceleyerek parçaların bütünü nasıl oluşturduklarını anlamaya çalışmaktadır. Son zamanlardaki il, ilçe ve belde incelemeleri bunu açıkça göstermektedir.

45 İdil Baran, Cengiz Bektaş, (1976), "Kentlerin Planlanmaları ve Korunmaları Üzerine Eleştiri ve Öneriler Safranbolu Örneği”, MTRE Bülteni, S.5-6,C.2; Reha Günay, (1998), Türk Ev Geleneği ve Safranbolu Evleri, s.99103. 


\section{KAYNAKÇA}

Aksoy, M. (1997). Doğu Anadolu. İstanbul.

Akozan, F. (1976). "Geçmişimiz İçin Gelecek", Kültür ve Sanat Dergisi, Haziran.

Baran, İ. \& Bektaş, C. (1976). "Kentlerin Planlanmaları ve Korunmaları Üzerine Eleştiri ve Öneriler Safranbolu Örneği”, MTRE Bülteni, S.5-6,C.2.

Başer, S. (1995). Kutatgu Bilig'de Kut ve Töreden Sevgi Toplumuna, İstanbul.

Bernheim, E. (1936). Tarih Ilmine Giriş, Tarih Metodu ve Felsefesi. Çev. M. Şükrü Akkaya. İstanbul: Kültür Bakanlı̆ğ Yay.

Braudel, F. (1992). Tarih Üzerine Yazılar. Ankara: İmge Yayınları.

Bruhl, L. L. ( 1970). Comte Felsefesi ve Sosyolojisi. Çev. Z.F. Fındıkoğlu. İstanbul.

Cansever, T. (1992). Şehir ve Mimari. İstanbul.

Carr, E. H. (1972). What is History?,Alfred A Knopf Inc, New York.

Çetinor, B. (1976). "Safranbolu Evleri”, Ilgi Dergisi, Mayıs Sayısı.

Collıngwood, R. G. (1990). Tarih Tasarımı. Çev. Kurtuluş Dinçer, İstanbul: Ara, Yay.

Debbins, W. (1965). Essays in the Philosophy of History by R. G. Collingwood, Austin: University of Texas Press.

DİE. (1927). 1927 Y11ı Genel Nüfus Sayımı Verileri.

Durant, W. A. (1992). Tarihten Dersler. Çev. Bozkurt Güvenç. İstanbul.

Erginsu, Z. (1975). Avrupa Mimari Mirası Y1l1 1975 Kampanyası münasebetiyle Safranbolu Mimari Değerleri ve Folkloru Haftası ve Sorunları. İktisat Dergisi, Eylül, Sayı 133.

Ergun, D. (1982). Sosyoloji ve Tarih. İstanbul.

Evans, R. (1999). Tarihin Savunusu. Ankara: İmge Yayınları.

Eyüboğlu, İ. Z.(1991). Tarihin Illkeleri, İstanbul: Say Yay.

Fontana, J. \& Carr, E. H. (1992). Tarih Yazımında Nesnellik ve Yanlılık. Ankara: İmge Yayınları.

Gökberk, M. (1948). Kant ve Herder'in Tarih Anlayışları. İstanbul.

Grace, C. (1962). Philosophies of History. New York.

Grunberg, T. (1985), "Neopozitivizm'in Bilim Anlayışının Eleştirisi”, Bilim Kavramı Sempozyumu Bildirileri, Ankara: Ankara Üniversitesi Basımevi, Ankara, ss.33-34.

Günay, R. (1998). Türk Ev Geleneği ve Safranbolu Evleri.

Gürsel, S. (1976). "Safranbolu'da Etnik Yap1 ve Kültür Değişimleri”, MTRE Bülteni, S.5-6,C.2.

Habermas, J. (1998). Sosyal Bilimlerin Mantığı Üzerine. Çev. Mustafa Tüzel. İstanbul: Kabalcı Yay. Haldun, İ. (1991). Mukaddime. C1. Çev: Z. K. Ugan. İstanbul.

Halkın, L. E. (1989). Tarih Tenkidinin Unsurları. Çev. Bahaeddin Yediyıldız. Ankara: Türk Tarih Kurumu Yay.

Hassan, Ü. (1982). İbn Haldun: Metodu ve Siyaset Teorisi. Ankara: Sevinç Matbaası.

Herder, İ.Q. (1984). Insanlık Tarihi Düşüncesi Üzerine Düşünceler. Çev. Doğan Özlem. Tarih Felsefesi Ek-2, İzmir.

Hobsbawm, E. (1999). Tarih Üzerine. Çev. Osman Akınhay. Ankara: Bilim ve Sanat yayınlan.

Hofstadter, A. (1963). "The Philosophy in History", Philosophy And History. Ed. Sidney Hook, New York University Press.

Hogan, J. H. (1989). Collingwood and Theological Hermeneutics, College Theology Society. New York.

Iggers, G. G. (2000). Yirminci Yüzyılda Tarih Yazımı. İstanbul: Tarih Vakfı Yurt Yayınları.

İnce, Y. (1975). Kentlerin Tarihsel Dokusunun Korunmasinda Yerel Örgütlerin Kurulması ve Bölgesel Eğitim Birimlerinin Oluşturulması. ITÜ MTRE Bülteni, Sayı 4, İstanbul.

Jenkins, K. (1997). Tarihi Yeniden Düşünmek. Ankara: Dost Yayınları.

Karabük Valiliği. (1999). Il Yıllığl. İl Kültür Müdürlüğü.

Karadeniz, E. (1975). "Safranbolu Mimari Değerleri ve Folkloru Haftası Bugün Başlıyor", Cumhuriyet, 30 Ağustos.

Kuban, D.,(1966). Anadolu- Türk Şehri Gelişmesi, Sosyal ve Fiziki Özellikleri Üzerine Bazı Gelişmeler Vakıflar Dergisi, Sayı VIII, İstanbul. 
Kuban, D. (1976). "Safranbolu Olay1", Cumhuriyet Gazetesi, 2 Eylül.

Kuş, A. \& Aksoy, M. (1992). Müze Kent Safranbolu, Kasım, Karabük.

Kuzucular, K. (1976). Safranbolu Çarşıs1. Türkiye Turing ve Otomobil Kurumu Belleteni, S.54/333, Temmuz-Ağustos.

Kütükoğlu, M. K. (1994). Tarih Araştırmalarında Usûl. 3. Basım. İstanbul: Kubbealtı Neşriyatı.

Lowith, K. (1984). Vico. Çev. Doğan Özlem. Tarih Felsefesi Eki. İzmir.

Marx, K. \& Angels, F. (1975). Felsefe incelemeleri. Çev. Sevim Belli. Ankara.

Oral, Z. (1976). "Türk tipi evlerin tüm özelliklerini taşıyan Safranbolu evlerinin korunması Zorunludur", Milliyet Sanat Dergisi, 26 Kasım.

Özlem, D. (1986). Kültür Bilimleri ve Kültür Felsefi. İstanbul.

Rabinow, P. \& Sullivan, W. (1990). "Yorumcu Eğilim: Bir Yaklaşımın Doğuşu”, Toplum Bilimlerinde Yorumcu Yaklaşım. Çev.: Taha Parla. İstanbul: Hürriyet Vakfı Yay.

Ranke, L. Von. (1952). Histories of the Latin and German Nations from 1494 to 1514, 2.Bask1, Longman.

Rotenstreich, N. (1976). Philosophy, History and Politics (Studies in Contemporary English Philosophy of History). Martinus Nijhoff- The Hague.

Rothacker, E. (1990). Tarihselcilik Sorunu. Çev. Doğan Özlem. İstanbul: Ara Yayıncılık.

Saari, H. (1998). "Collingwood'un Mutlak Ön-kabuller Öğretisinin Bazı Yönleri". Çev. Kubilay Aysevener, Doğu Batı, 1998/3, Say1 3, ss. 161-174.

Sarokin, A. P. (1972). Bir Bunalım Çağında Toplum Felsefeleri. Çev. Mete Tuncay. Ankara.

Sözen, M. (2003). Safranbolu ve Anitlar Konusunda Kısa Bilgiler, Kentin Tarihi ve Mimari Değerleri, Türkiye'de Mimarlık Değerlerinin Korunmasında İlk Adımlar. Karabük: Güven Ofset.

Sözer, Ö. (1977). Edmund Husserl'in Fenomenolojisi ve Nesnelerin Varlı̆ğ. İstanbul.

Sözer, Ö. (1981). Anlayan Tarih. İstanbul.

Sözer, O. (1983), "Dünya Tarihi ve Özgürlük İfadesi ", Macit Gökberk Armağanı. Ankara.

Toprak, Z. (1986). "Türkiye'de Çağdaș Tarihçilik (1908-1970)", Türkiye'de Sosyal Bilim AraştırmalarınınGelişimi. Der: Sevil Atauz. Ankara: Türk Sosyal Bilimler Derneği Yayını.

Tosh, T. (1991). The Pursuit of History; Aims, Methods, and... (Tarihin Peşinde, Çev. Özden, Arikan). Longman. London.

Toynbee, A. J. A. (1953). Civilization on Trial, London.

Toynbee, A. J. A. (1978). Tarih Bilinci. İstanbul: Bateş Yayınları.

Tör, V. N. (1977). "Safranbolu'daki Evlerin Dersleri," Milliyet, 13 Mart.

TUIK. (2016). 2016 Yılı Nüfus Sayımı Verileri. Ankara.

Tunçözgür, Ü. (2002). Dünü ve Bu Günü ile Safranbolu. Safranbolu: Iş11 Yayıncılık.

Uçar, Ş. (1994). Tarih Felsefesi Yazıları, Ankara.

Ulukavak, K. (1976). "Safranbolu Kentinin Mimari Değerlerinin Korunmas1, Sorunlar1 ve Safranbolu Belediyesi", MTRE Bülteni, S.5-6, C.2.

Ulukavak, K. (2003). Kentin Tarihi ve Mimari Değerleri, Türkiye'de Mimarlık Değerlerinin Korunmasında İlk Adımlar. Karabük: Güven Ofset.

Uygur, N. (1972). Edmund Husserl'de Başkasının Ben'i Sorunu. İstanbul.

Yazıcıoğlu, H.,(1982). Safranbolu, Karabük: Özer Matbaası.

Yediyıldız, B. (1990). "Çağdaş Tarihçilik", Tarih Metedolojisi ve Türk Tarihinin Meseleleri Kollokyumu (Haz. Abdülkadir Yuvalı), Elazığ: 1990, ss. 25.

West, D. (1998). Kıta Avrupası Felsefesine Giriş. Çev. A. Cevizci. İstanbul: Paradigma Yay. 